论 文

\title{
禹州植物群一一、晚期华夏植物群之瑰宝
}

\author{
杨关秀 ${ }^{(1)}$ ，王洪山 ${ }^{(2)}$ \\ (1) 中国地质大学地球科学与资源学院, 北京 100083 ; \\ (2) Florida Museum of Natural History, University of Florida, Gainesville, FL 32611, USA \\ * 联系人, E-mail: zengyangjh@163.com; \\ †联系人, E-mail: hwang@flmnh.ufl.edu
}

收稿日期: 2012-02-24; 接受日期: 2012-05-25

国家自然科学基金(批准号: 48970070, 49472075)和国家科技基础研究平台“国家岩矿化石标本资源共享平台”资助

摘要华北地台南部的禹州植物群是二叠纪中、晚期华夏植物群中最具区域特色的植 物群. 由于本区长期处于低纬度滨海潮坪, 三角洲的暖湿气候环境, 发育了化石层位多 而连续、数量丰富、演化序列完整、保存完好的植物群. 这是研究中、晚期华夏植物群 得天独厚的最佳地区. 经研究该植物群共计 111 属 307 种. 典型的类群有: 节烣植物 Lobatannularia 的形态演变快, 垂向分布有一定规律, 是华北二叠系生物地层划分依据之 一. 真䓲植物门中 $90 \%$ 为莲座蕨目, 在禹州植物群的早、中期很发育, 晚期突然衰退. 前 裸子植物㼼叶目繁盛. 古相种子烣只盛于中二叠世。进步种子蕨盾籽目极度发育于晚二 叠世早期末. 其中 Shenzhouphyllum 是晚期禹州植物群中的特色植物之一。苏铁植物在本 区始现校早, 并迅速分化繁衍于中二叠世晚期至晚二叠世早期. 银杏植物门种数虽少, 但数量极丰富, 大量繁盛于晚二叠世早期. 前有花植物大羽羊齿目, 在禹州植物群中占 有十分重要的地位, 是本植物群中最具特色的珍奇类群. 根据大羽羊齿目的脉序特征和 叶结构所呈现的规律性, 可划分出始现及分化, 首次繁盛, 再度繁盛及突然消失三个演 化阶段, 成为华北地区二叠系生物地层划分对比的依据. 本文特别指出脉序作为维管植 物的输导体系在植物演化中的重要意义. 同时据脉序和叶结构演变特征, 把大羽羊齿目 的属级分类进行了较大调整。禹州植物群始于早二叠世中期 (紫松期) 到晚二叠世早期 (吴家坪期) 突然消失, 随之为晚二叠世晚期的欧美型镁灰岩植物群所代替. 根据禹州植 物群各类群发育呈现出明显的阶段性, 该植物群的发展历程可划分为早、中、晚三个时 期. 根据禹州植物群各类群的兴衰, 演替和各类群在不同层位中的组合特征, 禹州植物 群自下而上可划分为 5 个植物化石组合带.
关键词

华北地台南部

二叠纪

中、晚期华夏植物群 禹州植物群
禹州植物群是东亚地区中、晚期华夏植物群中最 具区域特色的植物群. 在二叠纪, 中国华北地台南部 位于古特提斯洋东北侧分支的北沿 ${ }^{[1]}$. 特殊的古地理
位置决定了该区具有华北型, 华南型沉积和生物群 的过渡特征. 历来以具 “北型南相”的含煤地层而驰 名于世 ${ }^{[2]}$. 华南地台在二叠纪时海域范围广, 海侵时

英文引用格式: Yang G X, Wang H S. Yuzhou Flora-A hidden gem of the middle and late Cathaysian Flora. Sci China Earth Sci, 2012, doi: 10.1007/s11430$012-4476-2$ 
期多, 所含丰富的海相化石虽是区域地层对比的重 要依据, 但却中断了华南地台上陆生植物的发展序 列. 而同时期, 华北地台南部的豫西-皖北海湾 ${ }^{[3]}$, 间 隔古特提斯洋与华南地台南北相望. 长期处于低纬 度陆表海, 滨海, 潮坪和三角洲暖湿气候环境 ${ }^{[4]}$. 在 那里, 既发育有华北二叠系海相地层及化石, 易与华 南地台滇, 黔, 闽, 赣等地相关地层对比; 同时植物 化石层位多, 数量丰富, 保存完好, 重要植物类群演 化序列发育完整, 是研究中、晚期华夏植物群和华北 地台区域地层对比之最佳地区. 禹州植物群中发现 的古老苏铁最多; 有节植物形态演化趋向明显; 真鳜 植物的生殖蓱叶多样化, 最具研究价值; 大羽羊齿目 形态演替多样化, 显示了该类群自发生, 发展, 极盛 至突然消失的全过程. 华北地台的晚期华夏植物群 中, 只有本区保存了独具特色的丰富的最高化石层 位. 其组分以进化型种子䔊盾籽目, 大羽羊齿目和部 分裸子植物为主. 并在晚二叠世早期末为欧美型镁 灰岩植物群所替代 ${ }^{[5]}$.

禹州植物群的横向分布, 西起秦岭东端的豫西,
向东沿华北地台南部延伸, 经豫东至皖北, 大体相当 于徐州-郑州-西安一线以南. 由于豫东, 皖北覆盖多, 植物化石产出以河南禹州, 方山, 临汝一线及其以北 之新密, 登封, 伊川等地最佳. 其岩性, 岩相, 含煤 性和植物群面貌与华北中部不全相同, 具有大量地 方性特有分子, 形成独具特色的中、晚期华夏植物群, 故命名为“禹州植物群”. 典型剖面在禹州城区西南 约 $25 \mathrm{~km}$ 的牛头山大风口剖面及其东北面的云盖山 剖面 ${ }^{[6]}$ (图 1).

豫西地区的地层系统最早由孙健初 ${ }^{[7]}$ 建立. 他 指出了与山西上古生界最大不同处在于豫西二叠 系上部也含煤. 此后 70 余年中划分方案几经更改, 各家意见众说纷纭. 本文基本上沿用孙健初建立的 地层单位，并采用国际标准年代地层系统和中国区 域地层表二叠系三分方案 ${ }^{[8]}$. 据此, 豫西地区晚古生 代地方性地层单位名称自下而上分为:下二叠统朱 屯组, 中二叠统下部神厔组, 中二叠统上部小风口 组, 上二叠统下部云盖山组, 上二叠统上部三峰山 组 ${ }^{[9,10]}$.



图 1 禹州植物群剖面和化石点分布图 


\section{1 禹州植物群的植物学性质}

禹州植物群经研究共计 111 属 307 种, 分属于 12 个植物类别. 各类群属种总数和在植物群中所占比 例，如表 1 .

禹州植物群的组成分子绝大多数是华夏植物群 的特有属种, 几占总数的 2/3. 如: Lobatannularia, Fascipteris, Tingia, Yuania, Emplectopteridium, 和大 羽羊齿目各属: Emplectopteris, Progigantonoclea, Gigantonoclea, Progigantopteris, Pinnagigantonoclea, Monogigantonoclea, Pinnagigantopteris, Monogigantopteris, Gigantogramme, Neogigantopteridium. 进步种 子蕨植物盾籽目的 Shenzhouphyllum (包括 Psygmophyllum multipartitum 等 3 种), 银杏植物 Sphenobaiera, Rhipidopsis, Pseudorhipidopsis, Saportea. 它们也都是只见于华夏植物区二叠纪的珍奇植物. 禹州植物群中蕨类植物 (146 种) 和种子植物 (160 种) 所占百分比分别为 $47.7 \%$ 与 $52.3 \%$. 但至晚二叠 世早期，种子植物比例突然增大，占全部植物群的 3/4. 禹州植物群各类群的基本特征分述如下(各类群 属种名单可参见文献[6]中表 4-1).

\section{1 石松植物门}

全部属于鳞木目, 属种数不多, 但在朱屯组和神 厓组中丰度较高, 是早二叠世至中二叠世早期主要 聚煤植物之一, 向上渐少, 但可延续至上二叠统下部 的云盖山组. 除了 Bothrodendron 与欧美植物区分子 可能相关外, 常见的 Lepidodendron, Cathaysiodendron 等属种, 都是华夏植物区特有种, 即东方型

\section{表 1 禹州植物群各类群属、种数及其百分比}

\begin{tabular}{|c|c|c|c|}
\hline 类别 & 属 & 种 & 种的百分比 $(\%)$ \\
\hline 石松门鳞木目 & 8 & 16 & 5.21 \\
\hline 节蕨门楔叶目，木贼目 & 11 & 56 & 18.24 \\
\hline 真蕨门莲座蕨目及形态属 & 13 & 60 & 19.54 \\
\hline 前裸子植物门慓叶目 & 5 & 14 & 4.56 \\
\hline 种子蕨门各目及形态属 & 15 & 30 & 9.77 \\
\hline 苏铁门苏铁纲苏铁目及形态属 & 12 & 36 & 11.73 \\
\hline 银杏门银杏目 & 4 & 7 & 2.28 \\
\hline 松柏门科达纲、叉叶纲 & 9 & 12 & 3.91 \\
\hline 松柏门松柏纲 & 1 & 1 & 0.33 \\
\hline 裸子植物分类不明 & 2 & 6 & 1.95 \\
\hline 种子 & 14 & 28 & 9.12 \\
\hline 前有花植物大羽羊齿目 & 12 & 36 & 11.73 \\
\hline 植物分类不明 & 5 & 5 & 1.63 \\
\hline 总计 & 111 & 307 & 100 \\
\hline
\end{tabular}

鳞木 ${ }^{[11]}$. 中二叠统上部小风口组中的 Yangzunyia, 其 特征则与华南的苏, 浙, 闽地区龙潭组中发现的 Lepidodendron polygonale 最相近.

\section{2 节䕋植物门}

本门的两大类群楔叶目和木贼目都很发育, 占 禹州植物群属种总数的 $18.24 \%$, 居第二位. 楔叶目 在早二叠世和中二叠世早期，欧美区和华夏区的 Sphenophyllum 皆有发现. 中二叠世晚期小风口组至 晚二叠世早期云盖山组中 Sphenophyllum 则全部是华 夏区特有种. 叶的形态, 排列方式和脉序细节多样 化, 并发育多种具主脉的类型. 楔叶属叶形态的多样 性反映了该属在暖湿荫蔽的林下层环境中，为达到 最大限度地吸收阳光和加强输导能力的进化趋向.

木贼目的芦木科各属亦为本区聚煤植物之一. 华夏植物群中, 二叠纪叶化石特有属 Lobatannularia 在本区始现于中二叠世神厓组直延至晚二叠世云盖 山组顶部, 产出层位多达 22 个. 该属由始现, 繁盛至 突然消失, 形态演变快, 垂向 ${ }^{[12]}$ 分布有一定规律, 是 华北地台二叠系生物地层划分的依据之一.

晚二叠世早期云盖山组中，本区和安加拉植物 区, 冈瓦那植物区一样, 草本木贼科兴起, 除了 Schizoneura 外, 并发育了具叶鞘的 Szecalamitina yangiae.

\section{3 真烣植物门}

真蕨植物在禹州植物群中属种数占 $19.54 \%$, 居 于首位，其中莲座烣目及其形态属又几占 9/10. 这类 树蒝植物在早、中二叠世的潮坪和三角洲平原低地中 亦是重要的聚煤植物. 归于本目的自然属有 Scolecopteris, Qasimia, Asterotheca ${ }^{[13,14]}$. 相关的形态属除多 达 23 种的 Pecopteris 外, 还有 Fascipteris 是华夏植物 区二叠纪特有的标志分子. 晚二叠世早期莲座嵚目 突然衰退, 形态属种数量骤减 $2 / 3$, 代之以中生代型 的形态属 Cladophlebis. 此外, 据生殖叶研究, 尚有 薄囊蕨目的里白科, 膜蕨科及少数可能属于?紫萁科 的代表.

\section{4 前裸子植物瓢叶目}

该目 Tingia 和 Yuania 是华夏植物区二叠纪特有 的常见属. 前者在本区中、晚二叠世时很丰富, 上二 叠统云盖山组的暖湿池沼低地环境中发育达到极

1194 
盛期. Tingia polymorpha, T. taeniata 枝条两侧的大叶 长可达 15 20 cm. Disinites 也产出于同样环境. 刘照 华等 ${ }^{[15]}$, 王军等 ${ }^{[16]}$ 分别从叶表皮结构和植物生存环 境的分析, 认为在华夏植物区内, 漂叶目主要发育于 光照较弱, 环境湿热的低地植物群落中.

\section{5 种子蒝植物门}

常见于欧美区石炭纪的古相种子偋 ${ }^{[17]}$, 其形态 属有多种类型. 但豫西地区下、中二叠统的朱屯组, 神厔组中除少数是欧美区分子, 如 Autunia conferta, Neuropteris ovata, Odontopteris subcrenulata 外, 绝大 多数是华夏区的特有分子, 如 Callipteridium tachingshanense, Alethopteris norinii, A. ascendens, Mariopteris hallei, Emplectopteridium alatum. 小风口 组和云盖山组中则以进步种子蒝的盾籽目为主, 形 态属的代表属有 Protoblechnum 和 Neuropteridium 等. 上二叠统云盖山组的中上部, 盾籽目突然繁盛, Shenzhouphyllum (包括 Psygmophyllum multipartitum 等 3 种) 多达 6 种, 形态多样化, 数量丰富. 相关的雌, 雄 性生殖器官化石有 Shenzhouspermum, Shenzhoutheca (文献[6], 图版 29 33). 此外, 叶部着生种子的还有 Henanopteris 和 Fascipteridium. 新兴进步种子蒝植物 的叶膜都覆有厚的角质层, 反映出华北地台南部在 晚二叠世早期末, 古气候已转向干旱.

\section{6 苏铁植物门}

本区共发现苏铁植物 13 属 36 种, 占禹州植物群 总数 $11.73 \%$, 居第三位. 中二叠统下部神厓组中, 除 个别种外, 苏铁型叶体积小, 叶质薄. 重要分子有 Taeniopteris 型叶多种和连生大孢子叶的 Procycas 和 Cathaysiocycas $^{[18,19]}$. 而在小风口组和云盖山组中, 苏铁植物已是植物类群中的重要组份, 常构成地势 相对较高的高地植物群落, 叶体积大而叶质厚. 除了 Taeniopteris, Lesleya, Nilssonia 和 Ctenis 等叶化石外, 还有较多的大孢子叶化石, 如: Primocycas, Primozamia, Liella 和 Phasmatocycas. 上二叠统云盖山组的苏 铁植物形态已近中生代色彩. 小孢子叶球 Pania 的小 孢子叶形态也与现代的苏铁 Cycas revoluta 相近. Mamay ${ }^{[20]}$ 在北美中二叠世早期地层 Leonardian 阶发 现苏铁植物的大孢子叶为带羊齿型, 从而使带羊齿 型叶有了确切的自然分类归属. 华北地台中、南部二 叠系也发现较多带羊齿与苏铁植物的大, 小孢子叶
(球)共生的实例. 从“点断平衡论”分化的渐变和突变 规律分析, 苏铁植物在二叠纪应当是始现, 分化和迅 速繁盛的突变阶段. 这与华北地台中、南部的古气候 地理发展变化是相符的.

\section{7 银杏植物门}

银杏门或可能属于银杏门的植物仅占全植物群 属种总数的 $2.28 \%$, 但数量却极丰富. 它们在中二叠 统上部小风口组四煤段中始现, 有 Saportea nervosa 和 Rhipidopsis lobata. 该类群只在上二叠统下部云盖 山组才大量繁盛. 重要属有: Sphenobaiera tenuistriata, Rhipidopsis panii, Pseudorhipidopsis brevicaulis 等.

\section{8 松柏植物门}

本门在植物类群中属种总数最少, 仅占 $0.33 \%$, 主要属于科达纲, 但产出量很大. 在朱屯组, 神厓组 中都较丰盛, 叶化石 Cordaites principalis, C. schenkii, 球果穗(花序) Cordaianthus, 髓核 Artisia 和茎的硅化 木都有发现. 科达类的植物体与鳞木同为朱屯组, 神 厔组的聚煤植物. 小风口组中又与节茨门之芦木目, 莲座硕目的辉木同为聚煤植物. 松柏植物叉叶纲的 Dicranophyllum 仅见于小风口组底部. 上二叠统下部 云盖山组的顶部, 发现有亚安加拉区的科达纲分子 Crassinervia, Nephropsis 和 Lepeophyllum 及松柏纲的 Walchia cf. bipinnata.

分类不明的裸子植物, 仅出现一属 Nystroemia reniformis $^{[21]}$, 是一种具高度特化的生殖枝 Nystroemia 和特异形态的叶 Chiropteris 的连合体. 仅 发现叶器官者仍暂归入 Chiropteris. Nystroemia 为湿 生植物, 始现并繁盛于中二叠统上部小风口组. 上二 叠统云盖山组为另一繁盛期.

\section{9 前有花植物大羽羊齿目}

前有花植物大羽羊齿目 ${ }^{[22]}$ 出现于华夏植物群 中、晚期. 在禹州植物群中该类群占有十分突出的地 位, 其丰盛的程度及清晰的演化序列世所罕见. 已知 垂向分布至少有 23 个层位以上, 共发现 12 属 36 种 ( 2 个未定种), 占禹州植物群属种总数之 $11.73 \%$, 与 苏铁植物门并列第三位 (文献[6], 图版 52 72). 在华 北地台中、南部, 自中二叠世早期至晚二叠世早期末 大约 $19 \mathrm{Ma}$ 年期间, 大羽羊齿目植物迅速完成了其始 现-繁盛-绝灭的进化全过程. 它是华夏植物区最具特 
色的珍奇植物. 根据该目在垂向上属种分布的兴衰, 脉序特征和叶结构的演变规律, 可分为始现及分化, 首次繁盛, 再度繁盛及突然消失三个演化阶段 ${ }^{[23]}$. 本目的演化阶段亦作为华北地区二叠系生物地层划 分对比的重要依据. 大羽羊齿目叶的脉序渐次复杂 化和叶结构逐步完善化呈现出明显的规律性.

\section{9 .1 脉序渐次复杂化}

维管系统是维管植物赖以生存的输导体系. 叶 片中的脉序是植物输导体系重要的末梢部位. 它们 与外界环境直接接触, 对外部环境的变迁反映尤为 灵敏. 因此, 叶片中的脉序, 特别是大型叶的脉序是 植物输导体系最直接的重要表征. 它和植物体内部 维管系统的解剖特征具有同等重要意义. 把大羽羊 齿类叶部脉序的演变仅看成是该类植物外部形态变 化的观点是片面的. 大羽羊齿类叶部脉序的垂向变 化准确地反映了该类植物输导系统的演化规律. 本 区大羽羊齿目在垂向演变过程中, 其叶片的脉序由 简单到复杂呈现出多样而具规律性的变化:

(1) 始现分化阶段：小羽片的侧脉二歧分叉结成 简单网眼. 如: Emplectopteris 和 Progigantonoclea 的 小羽片已逐步愈合成羽片, 自侧脉伸出的细脉二歧 分叉结成简单网眼. Cathaysiopteris 自侧脉伸出的细 脉成羽状, 是另一种演化趋向.

(2) 首次繁盛阶段: 中二叠世晚期, 大羽羊齿目 在爆发式成种作用中, 出现较多的新属种, 脉序发展 呈多样化. Gigantonoclea 的一至三级侧脉呈羽状, 末 级细脉则多次二歧分叉结成单网眼. Progigantopteris 初具维形的重网脉, 但末级细脉仍然二歧分叉. Gigantopteris 具重网脉序, 第二级或三级羽状侧脉结 成大网眼. 第 3 或第 4 级羽状脉结成小网眼形成重网. 而细脉 (或称盲脉) 则大多数不发育.

(3) 再度繁盛及特化阶段: Gigantopteris 的重网 脉进一步复杂化, 自 2 级或 3 级以上的侧脉开始形成 的重网脉可多达 3 4 级依次套叠, 最后网隙内还有细 脉 (盲脉), 并二歧分叉 1 3 次. 其复杂程度等同或甚 至超过现生双子叶被子植物叶重网脉序的级次. 在 晚二叠世早期末的热带干湿气候条件下, 大羽羊齿 目有的属还出现叶脉增粗, 叶边缘叶脉增粗成刺状 或叶体积缩小等适应干季的形态特征 ${ }^{[23]}$.

\subsection{2 叶结构完善化}

本区大羽羊齿目原始的代表 Emplectopteris 偋叶 多次羽状分裂，叶架呈两次二歧分叉状，近于种子蒝 植物 ${ }^{[24]}$. 较进化的 Gigantonoclea 叶结构呈硕型羽状 分裂，即䓲叶顶部有若干对未完全分裂的羽片合成 顶羽片 ${ }^{[23]}$. 进一步演变成真正的羽状复叶, 其蒝叶顶 部无顶羽片, 而为具柄的顶端小叶, 如: Pinnagigantonoclea, Progigantopteris. 另一类进化为单叶结构. 单叶具明显的叶柄, 叶柄腋部具芽, 如 Monogigantonoclea, Monogigantopteris. 羽状复叶和单叶的出 现，使大羽羊齿目的叶结构跨出了蓱型叶的范畴. 而 与双子叶被子植物的叶结构相似, 在其进化趋向上 是一个质的飞跃.

\subsection{0 种子}

禹州植物群中已发现的种子甚多, 已知 14 属 28 种, 占到植物群的 $9.12 \%$. 它们的着生方式及形态大 小各异.

种子个体小者(约 2 5 mm): 着生于叶或裂片顶 端, 盾盘状大孢子叶背部边缘, 叶或小羽片的中脉, 各级侧脉基部或边缘，有的聚集成果穗. 成熟后易于 脱落. 种子形态各异, 但多具刺, 具翅或被毛, 利于 风力散布.

种子个体巨大者，单个保存. 绝大部分外种皮厚, 有的还具硬的内种皮，表明已能在水体中漂浮传播.

\section{2 禹州植物群的植物化石组合带及对比}

根据本区二叠纪各类植物的兴衰，演替和各类 群在不同层位中的组合特征. 特别以大羽羊齿目, 节 硕植物的演替，中生代型种子烣，苏铁类，银杏类的 始现和繁盛特征为依据, 禹州植物群自下而上可划 分为 5 个植物化石组合带. 时代分别为：早二叠世 中、晚期, 中二叠世早期, 中二叠世晚期和晚二叠世 早期.

2.1 第 I 植物化石组合带: 斯氏鳞木-斜方鳞木-卵 脉羊齿组合带 (Lepidodendron szeianum-L. posthumii-Neuropteris ovata Assemblage Zone)

本组合带赋存于朱屯组. 植物化石发现于底部 铝土岩，中部砂泥岩段和上灰岩段近顶部. 共计 10 
属 13 种.

该组合带明显的特征是：植物类群单调而贫乏， 以东方型鳞木为主体, 次为科达植物, 还有少数节 偋, 真偋和种子蒴植物. 与广泛分布于华北地台中部 太原组中所产的植物化石面貌一致. 朱屯组的下灰 岩段夹 4 层灰岩 $\left(\mathrm{L}_{1} \sim \mathrm{L}_{4}\right)$ 其中富含篴类化石, 重要分 子有：Sphaeroschwagerina glomosa, Schwagerina cervicalis, Pseudofusulina uralica var. sphaerica ${ }^{[25]}$, 可 与我国广泛分布的二叠系底部紫松阶 Sphaeroschwagerina 带对比, 相当于国际标准阿瑟尔 阶 (Asselian) 的中部. 朱屯组中部砂泥岩段中有 $\mathrm{L}_{5}$ 灰岩, 所产篴类有: Schwagerina nobilis, Eoparafusulina bocki, E. contracta, Paraschwagerina 等, 与华 南早二叠世紫松期䉇类相当. 朱屯组上灰岩段 $\left(\mathrm{L}_{6} \sim \mathrm{L}_{8}\right)$, 产牙形石 Sweetognathus whitei 和簙类 Staffella ${ }^{[25]}$, 其 层位相当于我国南方一些地区下二叠统上部隆林阶. 综上所述, 本区第 I 植物化石组合带的时代应为早 二叠世紫松中期-隆林期(早二叠世中晚期), 相当于 国际标准阿瑟尔 (Asselian) 中期至亚丁斯克期 (Artinskian).

\section{2 第 II 植物化石组合带: 三角织羊齿-中国瓣轮} 叶-翅编羊齿-华夏羊齿组合带 (Emplectopteris triangularis-Lobatannularia sinensis-Emplectopteridium alatum-Cathaysiopteris whitei Assemblage Zone)

(1) 本组合带赋存于神厔组中. 在禹州大风口 剖面包含有 7 个植物化石层. 综合禹州大风口, 方山, 平顶山矿, 新密县, 登封县, 临汝县, 宜阳县等地相 当层位的化石, 第 II 植物组合带共有植物化石 43 属 90 种. 本植物组合带总貌中, 蕨类植物和裸子植物 的比例大致接近 $1: 1$, 以真䓲和种子䓲植物为主体, 次为节蒝植物. 其中东亚型的种有 60 个, 占本组合 带植物化石总数的 $2 / 3$, 居优势地位.

本组合带各重要类群的面貌为: 1) 大羽羊齿目 和瓣轮叶处于始现, 分化阶段. 前者都为原始型, 有 Emplectopteris, Progigantonoclea 和 Cathaysiopteris, 它们只出现在第 11 组合带中上部中. 瓣轮叶只有刚 分化出的 Lobatannularia sinensis, 偶有少量 $L$. ensifolia 始现. 2) 楔叶目繁盛, Sphenophyllum 等叶型 和具三对型的种同时存在. 但后者大都为初具叶镶
嵌, 而三对叶大小差别不大的种. 3) 莲座蒝目: 栉羊 齿类和古相种子葓植物形态属的属种较多. 㼼叶目 Tingia 繁盛. 4) 苏铁植物始现并迅速多样化. 5) 鳞木 目和科达纲属种虽不多, 但数量上可能超过其他各 类群, 是滨海潮坪沼泽中的主要聚煤植物.

第 II 植物组合带垂向上演替较明显, 中下部有 第 I 组合带的子遗分子: Lepidodendron posthumii, Neuropteris ovata 等. 中上部则陆续始现新兴的分子. 本组合带植物面貌在豫西各地基本一致. 各剖面产 出此组合带的层位中, 都没有出现确切的 Gigantonoclea. 而 Emplectopteris, Emplectopteridium, Lobatannularia sinensis 却一直延续到本组合带最上 部. 值得注意的是, 自豫西至两淮地区普遍见到 Emplectopteris triangularis, Emplectopteridium alatum, Cathaysiopteris whitei 三者在同一层中产出. 表明这 3 个种的分布在本区不存在上下层位关系, 而是同属 一个植物带的分子.

（2）第 II 植物化石组合带从总体面貌到重要代 表分子与华北地台各地, 朝鲜, 印尼等地区同时期的 植物群, 即李星学 ${ }^{[26]}$ 所建的中期华夏植物群都可对 比 (表 2,3). 比较而言, 越向华北地台的西北方向, 如: 宁夏葫芦斯台, 内蒙古准旗和甘肃龙首山等地欧 美型分子增多.

与周边地区含海相层相当的植物群比较, 可佐 证本区第 II 植物化石组合带的地质时代 (表 3)．1) 华北地台北缘镶黄旗 (翁牛特旗) 额里图组中植物 化石 9 属 16 种 ${ }^{[30,45]}$, 其中的大羽羊齿类植物化石的 脉序和叶结构与本组合带一样属于始现, 分化阶段. 额里图组向西相变为海相的三面井组, 含 Misellina ovalis, Parafusulina splendens 和 Monodiexodina, 其 时代应为中二叠世早期 (栖霞期). 2) 日本本洲北部 米谷群 (Maiya flora) ${ }^{[37,38]}$ 中有 Cathaysiopteris whitei 和大量的 Taeniopteris, 可与本组合带对比. 其上部 产筳类 Misellina claudiae, Pseudofusulina ambigua 和 Parafusulina 等, 时代亦属中二叠世早期. 3) 美国西 南部得克萨斯州中二叠统 Leonardian 阶的中上部产 出的大羽羊齿 Gigantopteridium americanum, Zeilleropteris wattii 和 Cathaysiopteris yochelsonii 等亦 属于大羽羊齿类始现, 分化阶段 ${ }^{[39,40]}$, 亦与本组合带 相当. 根据敷类化石归为 Kungurian ${ }^{[46]}$, 与我国中二 
表 2 华北二叠纪植物化石组合(带)划分对比

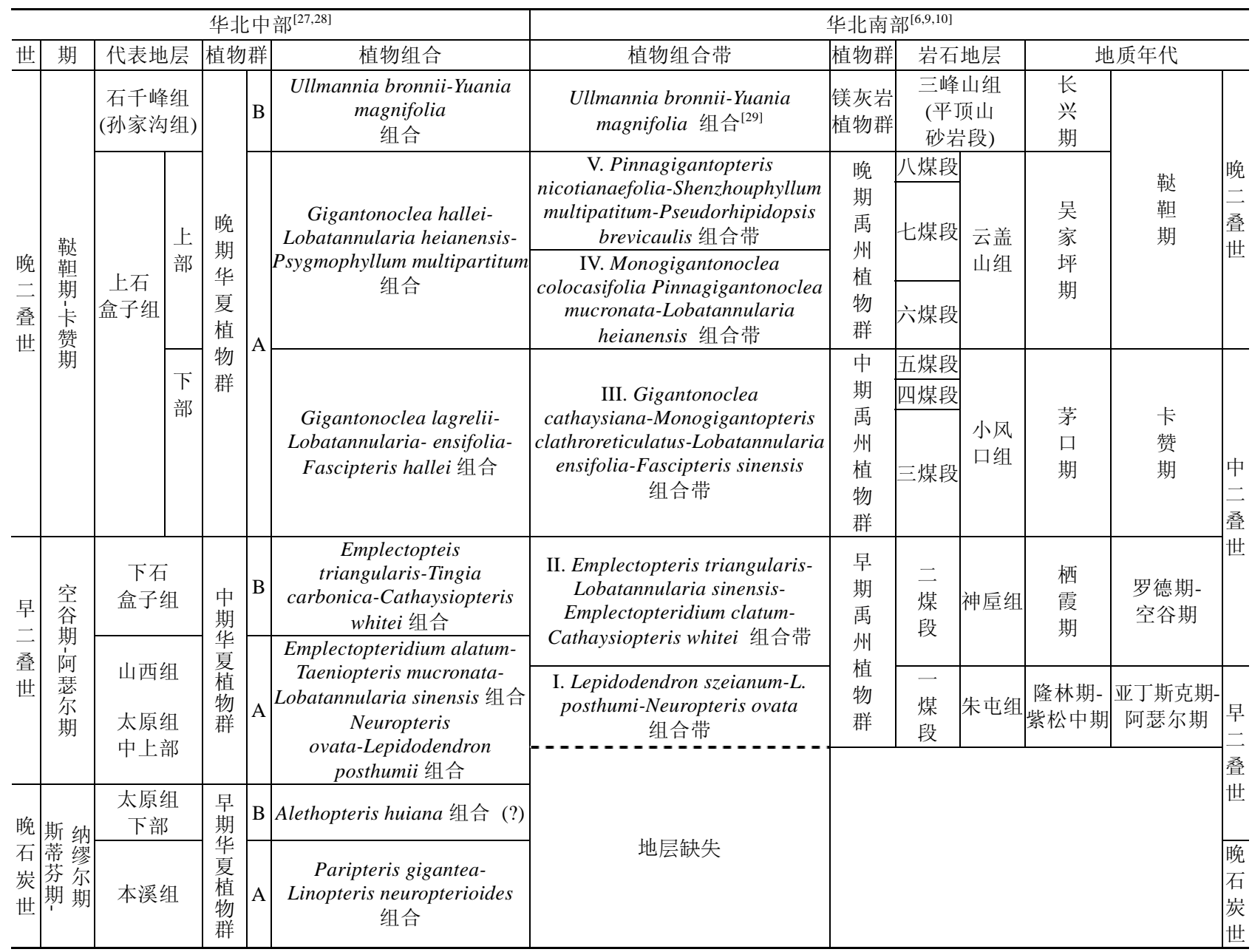

叠统下部相当.

2.3 第 III 植物化石组合带: 华夏单网羊齿-格网单 叶大羽羊齿-剑瓣轮叶-中国束羊齿组合带 (Gigantonoclea cathaysiana-Monogigantopteris clathroreticulatus-Lobatannularia ensifoliaFascipteris sinensis Assemblage Zone)

本组合带赋存于小风口组三、四、五煤段. 禹州 大风口剖面共有 16 个植物化石层. 综合禹州大风口, 方山, 登封县, 临汝县, 平顶山矿, 巩县, 宜阳县各 地相应层位所产化石, 归入本植物组合带的有 61 属 150 种. 茨类植物的种数稍大于种子植物. 华夏植物 区特有种已占组合带总数的 $4 / 5$ 以上, 居绝对优势.

\subsection{1 本组合带各类群突出的特征}

(1) 大羽羊齿目和瓣轮叶达首次繁盛阶段. 大羽
羊齿目偋型羽状分裂的 Gigantonoclea 最丰盛, 多达 7 种. 并始现真正羽状复叶的 Pinnagigantonoclea 和单 叶结构的 Monogigantonoclea. 其脉序也逐步复杂化, 有初具维型重网脉的 Progigantopteris 和真正重网的 Gigantopteris. 瓣轮叶多达 10 种, 半数以上的种其叶 瓣的叶大部分彼此分离, 其中 Lobatannularia ensifolia 在整个组合带是常见的优势种. 四煤段以上 出现叶彼此大部分相连合的种.

(2) Sphenophyllum 有 14 种, 形态多样化以具三 对型的种为主, 最突出的是发育了叶具主脉的类型.

(3) 真硕植物以莲座葓目为主. 包括: Scolecopteris, Qasimia, Asterotheca 和形态属 Pecopteris 及华夏区特有属 Fascipteris. 大多数是华 北中部上石盒子组中常见的种，部分为本区特有分 子. 甚至有华南中二叠世的 Pecopteris sahnii, P. 
表 3 豫西禹州植物群生物地层对比

\begin{tabular}{|c|c|c|c|c|c|c|c|c|c|c|c|c|}
\hline \multicolumn{2}{|c|}{$\begin{array}{l}\text { 地质 } \\
\text { 年代 }\end{array}$} & \multirow[t]{2}{*}{$\begin{array}{l}\text { 地 } \\
\text { 层 }\end{array}$} & \multirow{2}{*}{\multicolumn{2}{|c|}{$\begin{array}{l}\text { 豫西(本文) } \\
\\
\text { 孙家沟植物群 }{ }^{[29]} \text { : } \\
\text { Imania bronnii-Yuania } \\
\text { magnifolia 组合 }\end{array}$}} & \multicolumn{3}{|c|}{ 大兴安岭、内蒙古 ${ }^{[24,30]}$} & 黔西、滇东 ${ }^{[31]}$ & \multicolumn{2}{|r|}{ 赣中南、闽西 ${ }^{[11,32 ~ 36]}$} & \multicolumn{2}{|c|}{ 国外 } \\
\hline \multirow{3}{*}{$\begin{array}{l}\text { 乐 } \\
\text { 平 } \\
\text { 世 }\end{array}$} & $\begin{array}{l}\text { 长 } \\
\text { 兴 } \\
\text { 期 }\end{array}$ & & & & & & & $\begin{array}{l}\text { 宣威组上部植物: } \\
\text { Gigantopteris } \\
\text { dictyophylloides, } \\
\text { Ullmannia cf. } \\
\text { bronnii } \\
\text { 动物: } \\
\text { Palaeofusulina 带 }\end{array}$ & $\begin{array}{l}\text { 㭐 } \\
\text { 隆 } \\
\text { 组 } \\
\text { 长 } \\
\text { 兴 } \\
\text { 组 }\end{array}$ & $\begin{array}{c}\text { 动物: Palaeofusulina, } \\
\text { Waagenites, } \\
\text { Pseudotirolites }\end{array}$ & & \\
\hline & \multirow{2}{*}{$\begin{array}{l}\text { 吴 } \\
\text { 家 } \\
\text { 坪 } \\
\text { 期 }\end{array}$} & \multirow{2}{*}{$\begin{array}{l}\text { 云 } \\
\text { 盖 } \\
\text { 山 } \\
\text { 组 }\end{array}$} & & $\begin{array}{l}\text { Pinnagigantopteris } \\
\text { otianaefolia-Shenzhou- } \\
\text { ylum multipartitum- } \\
\text { eudorhipidopsis } \\
\text { evicaulis 组合带 }\end{array}$ & & & & \multirow{2}{*}{$\begin{array}{l}\text { 宣威组下部植物: } \\
\text { Gigantopteris } \\
\text { dictyophylloides, } \\
\text { Gigantonoclea } \\
\text { guizhouensis, } \\
\text { Rhipidopsis panii } \\
\text { 动物: } \\
\text { Codonofusiella, } \\
\text { Oldhamina, } \\
\text { Edriostege } \\
\text { poyangensis }\end{array}$} & \multirow{2}{*}{$\begin{array}{l}\text { 翠 } \\
\text { 屏 } \\
\text { 山 } \\
\text { 组 } \\
\text { 雾 } \\
\text { 霖 } \\
\text { 山 } \\
\text { 组 }\end{array}$} & \multirow{2}{*}{$\begin{array}{c}\text { 植物: Psygmophyllum } \\
\text { multipartitum, } \\
\text { Rhipidopsis panii }\end{array}$} & \multirow{2}{*}{\multicolumn{2}{|c|}{\begin{tabular}{|c} 
朝鲜高坊山群 \\
上部 ${ }^{[41 ~ 44]}$ : \\
植物 Lobatannularia \\
heianensis, \\
Gigantonoclea hallei, \\
Sphenobaiera \\
tenuistriata, \\
Psygmophyllum \\
multipartitum, \\
Pseudorhipidopsis \\
brevicaulis
\end{tabular}}} \\
\hline & & & \multicolumn{2}{|c|}{$\begin{array}{l}\text { IV. Monogigantonoclea } \\
\text { colocasifolia-Pinnagigan- } \\
\text { tonoclea mucronata- } \\
\text { Lobatannularia heianensis } \\
\text { 组合带 }\end{array}$} & & & & & & & & \\
\hline \multirow[t]{2}{*}{$\begin{array}{l}\text { 阳 } \\
\text { 新 } \\
\text { 世 }\end{array}$} & $\begin{array}{l}\text { 茅 } \\
\text { 口 } \\
\text { 期 }\end{array}$ & $\begin{array}{l}\text { 小 } \\
\text { 风 } \\
\text { 口 } \\
\text { 组 }\end{array}$ & \multicolumn{2}{|c|}{$\begin{array}{l}\text { III. Gigantonoclea } \\
\text { cathaysiana-Monogiganto } \\
\text { pteris clathroreticulatus- } \\
\text { Lobatannularia ensifolia- } \\
\text { Fascipteis sinensis } \\
\text { 组合带 }\end{array}$} & $\begin{array}{l}\text { 于 } \\
\text { 家 } \\
\text { 北 } \\
\text { 沟 } \\
\text { 组 }\end{array}$ & \multicolumn{2}{|c|}{$\begin{array}{c}\text { 动物: Pseudodoliolina } \\
\text { elongata, Parafusulina, } \\
\text { Leptodus } \\
\text { 植物: Gigantonoclea } \\
\text { yujiaensi, G. tiayinensis, } \\
\text { Fascipteris } \\
\text { kaishantunensis }\end{array}$} & & \multirow[t]{2}{*}{ 童 } & \multirow[t]{2}{*}{\begin{tabular}{|c} 
植物: Asterophyllites \\
longifolius, \\
Gigantonoclea \\
fukienensis, \\
Gigantopteris \\
nicotianaefolia \\
动物: Neomisellina, \\
Neoschwagerina, \\
Altudoceras, \\
Shouchangoceras \\
\end{tabular}} & \multicolumn{2}{|c|}{\begin{tabular}{|} 
朝鲜高坊山群中、下 \\
部 $^{[41 ~ 44]}$ : \\
植物: Lobatannularia \\
ensifolia, \\
Gigantonoclea yabei, \\
Fascipteris \\
chongsonensis
\end{tabular}} \\
\hline & $\begin{array}{l}\text { 栖 } \\
\text { 霞 } \\
\text { 期 }\end{array}$ & $\begin{array}{l}\text { 神 } \\
\text { 厘 } \\
\text { 组 }\end{array}$ & \multicolumn{2}{|c|}{$\begin{array}{l}\text { II . Emplectopteris } \\
\text { triangularis-Lobatannular } \\
\text { ia sinensis-Emplecto- } \\
\text { pteridium alatum-Cathay- } \\
\text { siopteris whitei } \\
\text { 组合带 }\end{array}$} & \begin{tabular}{|l|} 
额 \\
里 \\
图 \\
组 \\
\end{tabular} & $\begin{array}{l}\text { 下部植物: } \\
\text { Emplectoptleris } \\
\text { minima, } \\
\text { Gigantonoclea } \\
\text { borealia }\end{array}$ & $\begin{array}{l}\text { 三 } \\
\text { 面 } \\
\text { 井 } \\
\text { 组 } \\
\text { d) }\end{array}$ & & & & b) & c) \\
\hline \multirow{3}{*}{$\begin{array}{l}\text { 船 } \\
\text { 山 } \\
\text { 世 }\end{array}$} & \begin{tabular}{l|} 
隆 \\
林 \\
期 \\
\end{tabular} & \multirow{3}{*}{$\begin{array}{l}\text { 朱 } \\
\text { 屯 } \\
\text { 组 }\end{array}$} & \multirow{3}{*}{\multicolumn{2}{|c|}{\begin{tabular}{l|} 
I \\
植 \\
物 \\
组 \\
合 \\
带 \\
a)
\end{tabular}}} & \multirow{3}{*}{\multicolumn{8}{|c|}{ 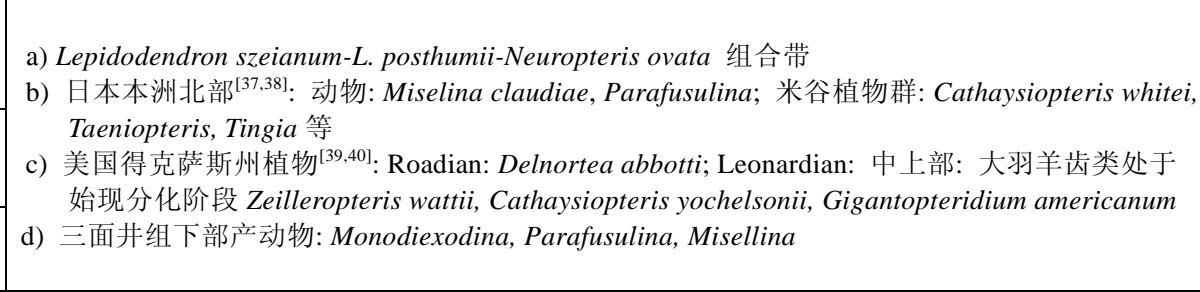 }} \\
\hline & \begin{tabular}{l|} 
紫 \\
松 \\
中
\end{tabular} & & & & & & & & & & & \\
\hline & $\begin{array}{l}\text { 晚 } \\
\text { 期 }\end{array}$ & & & & & & & & & & & \\
\hline
\end{tabular}

echinata. Scolecopteris 叶具三次羽状分裂, 其硕叶的 一部分就长达 $1 \mathrm{~m}$ 以上, 被覆在坑道的顶板上 (平顶 山矿). 表明树葓植物最可能也是小风口组的聚煤植 物. 此外, 有少数薄囊硕目各科分子.

（4）苏铁植物进一步分化, 迅速繁衍. 除了 Taeniopteris 外, 叶化石有 Lesleya, Nilssonia, Ctenis 和若干具肧珠的大孢子叶 Primocycas, Phasmatocycas, Liella 和 Primozamia.

(5) 古相种子蕨形态属有 Protoblechnum 和 Neuropteridium. 分类不明的裸子植物 Nystroemia,
和可能的银杏植物 Saportea nervosa 都属始现.

本组合带发育时期，本区仍处在滨海三角洲暖 湿气候环境中 $\left(\right.$ 为 $\left.11^{\circ} \mathrm{N}\right)$ 各类群植物全面繁荣. 组合 带中虽有 $4 / 5$ 以上的植物化石种与第 II 植物组合带不 同，但大类群相同，说明本组合带植物类群是在前期 基础上发展演化而来.

\subsection{2 本组合带时代讨论}

赋存本组合带的小风口组直覆于神厔组之上, 由 植物组合面貌以及相当层位的海相化石对比，其时 
代应归中二叠世晚期(表 2,3).

(1) 华北地台中部, 山西太原附近是我国华夏 植物群研究最早的地区 ${ }^{[47,48]}$. 经比较本区第 III 植物 化石组合带的植物面貌与太原东山, 西山的上石盒 子组中下部(或天龙寺组中下部 ${ }^{[49]}$ )最相似. 两者间 有相同或相似的共有分子, 但本区要丰盛得多. 本 组合带中已知有多达 9 属 17 种是国内外早, 中二叠 世分子. 第 III 植物组合带中还发现部分华夏植物地 理大区华南区的分子. 如 Asterotheca sahnii, Pecopteris echinata, Cladophlebis ozakii, Protoblechnum contracta, P. ellipticum 等. Qasimia lanceolata 和 $Q$. linearis 与沙特阿拉伯所产的 Qasimia schyfsmae 相似 ${ }^{\left[{ }^{[0]}\right.}$. Scolecopteris cathaysicus, S. henanensis 与粤北的 S. unifercata 相似 ${ }^{[1]}$. 表明禹州 植物群发展到中期时, 植物群面貌已明显兼具南, 北华夏植物地理区过度色彩.

(2) 华北地台北缘地区，内蒙古东部克什克腾 旗, 中二叠统于家北沟组的下部所含植物化石的组 合面貌和重要分子与本区第 III 植物化石组合带相似. 大羽羊齿目亦属首次繁盛期, 以 Gigantonoclea 为主. 于家北沟组上部产筫类, 腕足类和双壳类化石: Pseudodoliolina elongata, Parafusulina hexigteaensis 和 Chonetes matsuchitai, 时代属于中二叠世晚期 ${ }^{[52]}$.

(3) 华南地台东部闽西龙岩地区的含煤地层童子 岩组, 产菊石类 Altudoceras, Paracelites遥类 Neomisellina 等中二叠世晚期(茅口期) 动物群. 该组植物化 石丰富 ${ }^{[22,33,53]}$, 与本区第 III 植物化石组合带的植物面 貌相似. 从类别比较, 两者都以楔叶, 瓣轮叶, 大羽羊 齿类, 栉羊齿类和科达纲繁荣为特征. 但豫西地区的 瓣轮叶和苏铁植物比华南发育. 闽西、粤北等地的大 羽羊齿植物与豫西不同, 有 Gigantopteridium, Fujianopteris 和 Gigantonoclea 茨叶呈二歧分叉的类型 [44 56].

(4) 朝鲜北部高坊山群下部的植物化石 ${ }^{[11 \sim 44]}$, 与 本区第 III 植物化石组合带也相当.

上述对比表明，本区第 $11 \mathrm{I}$ 植物化石组合带具有 南北二叠纪华夏植物群的过渡特点. 于家北沟组和 童子岩组的动物化石佐证了本植物组合带的时代应 为中二叠世晚期(茅口期). 相当于欧洲, 北亚的喀山 期 (Kazanian), 即国际标准的沃德期至卡匹敦期 (Wordian-Capitanian).
2.4 第 IV 植物化石组合带: 芋叶单叶单网羊齿-尖 头羽叶单网羊齿 - 平安瓣轮叶组合带 (Monogigantonoclea colocasifolia-Pinnagigantonoclea mucronata-Lobatannularia heianensis Assemblage Zone)

本组合带赋存于云盖山组下部六煤段的上部. 发育较好的地区有禹州大风口和云盖山李家门剖面, 包括 P. 25 P. 26 化石层; 还有方山, 新密, 登封等地 相应的层位. 植物化石共计 27 属 44 种. 种子植物与 偋类植物数量近等. 除了极个别种外, 本组合带的植 物化石几已全部为华夏植物大区特有的属种。与第 III 植物化石组合带相比, 本组合带属种总数减少 $3 / 4$; 新兴分子占本组合带分子总数近 $1 / 2$. 䕬类植物总体 衰退明显。

几个重要植物类群的面貌为:

（1）节䓲植物木贼目的瓣轮叶进入另一演化阶 段. 除了少数种外, 叶几乎大部分或全部相连, 叶数 目相对较多. 如: Lobatannularia obtusa, L. heianensis 等. Annularia macronata 虽起自第 $11 \mathrm{I}$ 植物带, 却在本 组合带十分繁盛. Asterophylites 出现枝轴粗壮的新分 子. 楔叶目的 Sphenophyllum 总体上多样度低, 数量少.

(2) 大羽羊齿目在本组合带中为再度繁盛期, 共 有 6 属 13 种. 总体上以细脉结成单网隙类型为主. 在 第 III 植物组合带极盛的蒝型羽状复叶型已大为减少, 仅有 Gigantonoclea hallei一种. 具顶端小叶的羽状复 叶型继续发育, 有 Pinnagigantonoclea mucronata, P. guizhouensis, P. zelkovoides 等. 引人注目的是单叶有 柄，腋部有芽的单叶单网羊齿特别发育，有 Monogigantonoclea colocasifolia, M. rotundifolia, M. latiovata 和 M. aceroides. 重网脉序类型的属有来自 第 III 植物组合带的 Monogigantopteris clathroreticulatus. 重网脉序羽状复叶型 Pinnagigantopteris lanceolatus 和 P. nicotianaefolia 在本组合带始现.

(3) 栉羊齿类的 Pecopteris 和 Fascipteris 多样度 相对减少，有第 III 植物组合带延续的分子. 如: Pecopteris tenuicostata, P. andersonii, P. nervosa, Fascipteris sinensis, F. stena 等. 较发育的都是侧脉较 粗曾见于闽、粤等地区的 Pecopteris (Asterotheca) crassinervis. 此外Lixotheca (Cladophlebis) permica 在 本组合带始现.

（4）本区六煤段是下三角洲平原浅水湖泊沼泽 
的湿生环境. 大叶型的齿叶 Tingia polymorpha 始现. Nystroemia reniformis 很繁盛. 在这种湿生环境下苏 铁类植物相对并不丰盛, 只有 Taeniopteris densissima 和 Plagiozamites oblongifolius 等存在.

(5) 生活于高地的裸子植物银杏类 Sphenobaiera 在本植物组合带中出现.

2.5 第 $\mathrm{V}$ 植物化石组合带 烟叶羽叶大羽羊齿-多 裂神州叶-短柄异叶组合带 (Pinnagigantopteris nicotianaefolia-Shenzhouphyllum multipartitum-Pseudorhipidopsis brevicaulis Assemblage Zone)

本组合带赋存于上二叠统下部云盖山组七煤段 中上部至八煤段. 包括禹州大风口和云盖山剖面的 P. 27 P. 34, 共 8 个化石层. 还有临汝县坡池, 登封 县磴槽相应的化石层. 植物化石共计 58 属 91 种. 本 组合带中偋类植物已大为衰落, 属种数仅占全部种 数的 $1 / 4$, 而种子植物各类群属种数却占 $3 / 4$. 植物群 的基本组分有了重大的更替.

\subsection{1 各重要类群的面貌}

(1) 节蒝植物由第 IV 植物组合带延续的种有 Sphenophyllum speciosum, S. sino-coreanum, Annularia mucronata, Lobatannularia cathaysiana, L. heianensis 等. 本组合带还有草本木贼类植物 Schizoneura manchuriensis 和 Szecalamitina yangiae. 表明晚二叠 世早期, 在华夏植物大区同样有适应气候条件变更 的木贼科新兴分子出现. 鳞木目则仅有残留代表.

(2) 本区第 II 和 III 植物组合带中极盛的真偋门 莲座蒝目进入晚二叠世早期就极度衰落. Pecopteris, Fascipteris 等延续到本组合带更渐次减少. 而 Cladophlebis 蕨形叶却相应增多, 如：膜萨科 Lixotheca (Cladophlebis) permica 极盛.

(3) 漂叶目的 Tingia 在本组合带发育了叶最大的 两个种 Tingia polymorpha, T. taeniata. 还有 Yuania 及 盘穗 Discinites 等.

(4) 进步种子偋盾籽目的 Shenzhouphyllum 始现 于本组合带下部, 有: S. multipartitum, S. symetricum. 至本组合带上部达极盛, 重要分子有 Shenzhouphyllum aliretinervium, $S$. undulatum, $S$. rotundatum, $S$. spatulatum 等. 与之共生的生殖器官化石有 Shenzhouspermum trichotomum, Shenzhoutheca aspergilliformis 等, 从结构上它们与盾籽科 Peltasper- mum 最接近. 属于种子蒴的还有小羽片中脉上着生 种子的 Henanopteris lanceolatus 和单叶, 叶缘具种 子的 Fascipteridium ellipticum.

(5) 大羽羊齿目除个别种自第 III 和 IV 植物组合 带延续至本组合带下部外, 大多数为始现的新兴分 子, 其叶结构和脉序呈现多样性的适应. 濒型羽叶的 Gigantonoclea crassiglandula 具大而突起的腺点很可 能是吸引昆虫的蜜腺, 显示了大羽羊齿目机体组织 上的进化. 羽状复叶型的单网羊齿有的小叶体积大 (长 10 30 m), 如 Pinnagigantonoclea spatulata, P. rosulata. 但在本组合带顶部却发育了小叶体积小的 种 (长 4 9 m). 如: Pinnagigantonoclea polymorpha. 重网脉序型在本组合带最常见的种是 Pinnagigantopteris nicotianaefolia, 此种在临汝县坡池最高层位 可至云盖山组八煤段顶部 (上距上二叠统底部平顶 山砂岩仅 $1 \mathrm{~m}$ 处). 本组合带上部另一种类型为叶膜 较厚, 叶脉相对粗壮者, 以 Gigantogramme dengfengensis 为代表. 此外, 还有羽状脉级次达到 5 级的网脉, 盲脉多次二歧分叉的 Monogigantopteris densireticulatus.

（6）裸子植物的苏铁类丰富而多样化. Taeniopteris 属有: T. taiyuanensis, T. densissima, T. spatulata, T. hunanensis, T. sze $i$ 等种，其中前三者源 自第 III 植物组合带. 此外尚有: Pterophyllum, Nilssonia, Lesleya, Plagiozamites 和雄性球果 Pania. 总计有 5 属 12 种. 银杏类植物除在第IV 植物化石带 已始现的 Sphenobaiera tenuistriata 外, Pseudorhipidopsis bravicaulis, P. imparis 是本组合带特有的 分子. Rhipidopsis 在第 III 至第IV 组合带常有出现, 但 以本组合带最盛. 松柏类仅有少量的 Walchia cf. bipinnata 产出于本组合带. 引人注目的是本组合带 的中上部有亚安加拉区的科达类分子 Nephropsis, Crassinervia 和 Lepeophyllum 出现. 裸子植物分类不 明的 Nystroemia reniformis 大量产出于第IV 和 $\mathrm{V}$ 植物 组合带中.

\subsection{2 第 IV 和 $V$ 植物化石组合带的对比及时代讨论}

(1) 与山西太原地区，长治-临汾地区和垣曲地 区相关剖面中植物化石垂向分布比较(表 2，3). 潘钟 祥 ${ }^{[57]}$ 在禹州大风口层近顶部, 最早发现 Gigantopteris nicotianaefolia 和 Psygnophyllum multipartitum, 并认 
为与山西太原上石盒子系上部相当. 豫西云盖山组 第 $I V$ 和 $V$ 植物组合带的面貌与山西各地上石盒子组 上部 (天龙寺组上部) 的面貌较为接近. 总体上蒝类 植物衰落, 以旧种为主. 而前裸子植物漂叶目, 种子 植物中先进种子蒝盾籽目, 苏铁类, 银杏类植物, 大 羽羊齿目和 Nystroemia 比较发育. 两地共有分子为: Sphenophyllum sino-coreanum, S. speciosum, $S$. koboense, Annularia mucronata, Lobatannularia heianensis, Pecopteris orientalis, P. andersonii, $P$. nervosa, P. tenuicostata, Neuropteridium polymorphum, Lixotheca (Cladophlebis) permica, Yuania gigantea, Taeniopteris densissima, T. taiyuanensis, Plagiozamites oblongifolius, Shenzhouphyllum multipartitum, Gigantonoclea spp. (各地有不同的种), Sphenobaiera tenuistriata, Nystroemia reniformis 等. 但豫西第 IV 和 $\mathrm{V}$ 植物组合带的植物化石远比山西地区上石盒子组 上部丰富得多, 尤其是大羽羊齿目, 盾䊏目, 㼼叶目 各类群更为突出. 如豫西云盖山组第 $\mathrm{V}$ 植物组合带 中大羽羊齿目共有 7 属 13 种, 神州叶的叶和生殖器 官化石共有 3 属 8 种. 而华北中部山西各地上石盒子 组上部 (天龙寺组上部) 中大羽羊齿目仅有 Gigantonoclea, Jiaochengia 2 属 5 种, 神州叶仅有 Shenzhouphyllum multipartitum 一种.

从上覆地层比较, 华北中部上石盒子组顶部为 石千峰群下部的孙家沟组所覆; 在本区与之相当 的是云盖山组顶部为三峰山组所覆. 王自强 ${ }^{[29]}$ 等 研究确定孙家沟组植物群中相当部分是西欧晚二 叠世镁灰岩植物群(Zechstein flora)的代表分子, 以 Ullmannia bronnii 为优势种. 相反, 通常华夏植物群 的特征分子, 如 Tingia, Gigantonoclea, Gigantopteris, Lobatannularia, Fascipteris 等却突然消失. 孙家沟 植物组合应与西欧镁灰岩植物群相当, 时代为晚二 叠世晚期, 直伏其下的上石盒子组上部和豫西云盖 山组的时代应为晚二叠世早期为宜. 豫西平顶山 6309 钻孔中, 在三峰山砂岩下段 (平顶山砂岩段) 获 得孢粉组合, 以裸子植物种子颗和古松柏的花粉占 优势, 与山西离石的石千峰组孢粉组合十分相似, 其 中又以具胁纹的两囊粉为主, 代表属种 Lueckisporites virkkiae 为欧洲镁灰岩组标准分子 ${ }^{[58]}$. 佐证了豫西地区云盖山组第 IV, V 植物组合带时代为 晚二叠世早期.

(2) 华南地台含有大羽羊齿植物群的含煤地层
始自中二叠世晚期, 延至晚二叠世晚期. 含煤层位自 东向西渐次升高 ${ }^{[53,59]}$. 黔西, 滇东是华南含大羽羊齿 植物群层位最高的地区. 贵州水城 ${ }^{[00]}$ 和滇东宣威, 富 源等地 ${ }^{[31]}$ 的龙潭组或宣威组下部的植物组合与本区 第 IV 和 $V$ 植物组合带比较接近, 共有分子或可比较 的分子有: Sphenophyllum sino-coreanum, Annularia pingloensis, Lobatannularia cathaysiana, Schizoneura manchuriensis, Fascipteris stena, F. (Ptychocarpus) densata, Lixotheca (Cladophlebis) permica, Neuropteridium coreanicum, Protoblechnum contractum, Gigantonoclea hallei, Pinnagigantonoclea guizhouensis, $P$. rosulata, Pinnagigantopteris nicotianaefolia, Pterophyllum eratum, Plagiozamites oblongifolius, Rhipidopsis panii 等. 黔西、滇东龙潭组, 宣威组下段 产晚二叠世早期吴家坪阶以 Codonofusiella 为代表的 筳类动物群. 上覆地层汪家寨组或宣威组上段产长兴 阶的 Palaeofusulina guizhouensis 等鎑类动物群. 因此, 与龙潭组或宣威组下段相当的本区第 $I V$ 和 $\mathrm{V}$ 植物组 合带的时代，应归于晚二叠世早期为宜(表 3).

\section{3 禹州植物群的发展阶段}

禹州植物群始现于早二叠世中晚期, 是由早期 华夏植物群在特定的古气候地理条件下发展而来, 到晚二叠世早期末突然消失. 而代之以晚二叠世晚 期的镁灰岩植物群. 根据本项目在禹州大风口剖面 进行磁性地层研究的结果 ${ }^{[61]}$, 随着华北板块向北东 漂移及古环境的变迁, 禹州植物群各类群发育的特 点及其组分特征, 呈现出明显的阶段性. 据此, 禹州 植物群的发育历程可划分为 3 个阶段(图 2).

\section{1 早期禹州植物群：早二叠世紫松中期-中二叠 世栖霞期}

早二叠世, 华北板块南部经过长期风化剥蚀, 处 于 $10.8^{\circ} \mathrm{N}$ 赤道热带区的滨海环境. 接受了浅水碳酸 盐, 潮下潮间碎屑物和沼泽泥炭交互的沉积. 在底部 风化面上, 初步衍生出种类单调以鳞木目为主的滨 海潮坪湿生先锋植物. 并陆续有多次短期沼泽环境 形成薄煤. 栖霞期, 本区移至 $12.5^{\circ} \mathrm{N}$, 发育了滨海潮 坪热带沼泽植物, 形成本区主要可采煤层. 其后发育 了浅水湖泊和三角洲平原环境, 并为水下分流河道 沉积物覆盖 ${ }^{[4]}$. 植物组成(图 3) 以鳞木目, 科达目, 树

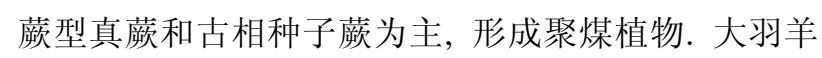




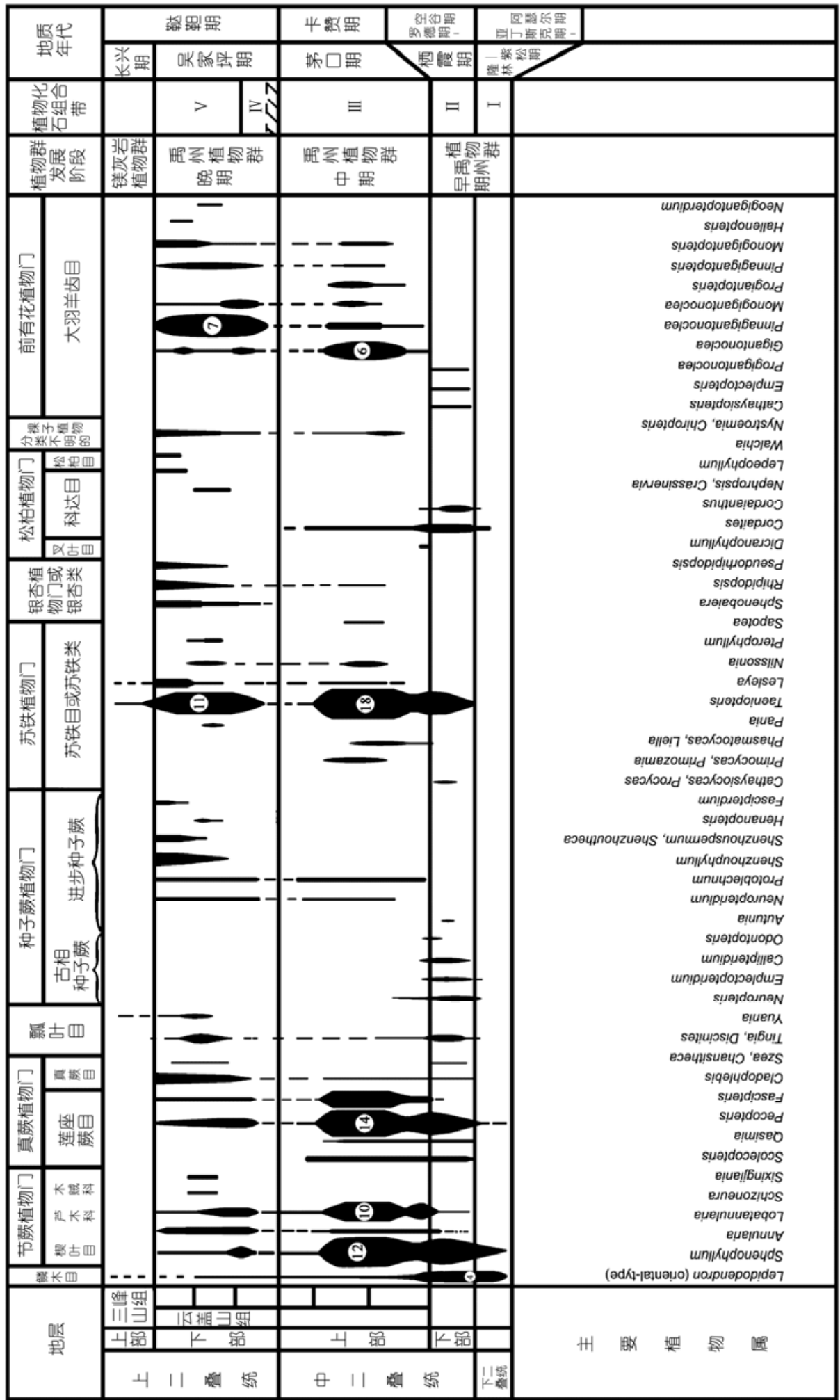




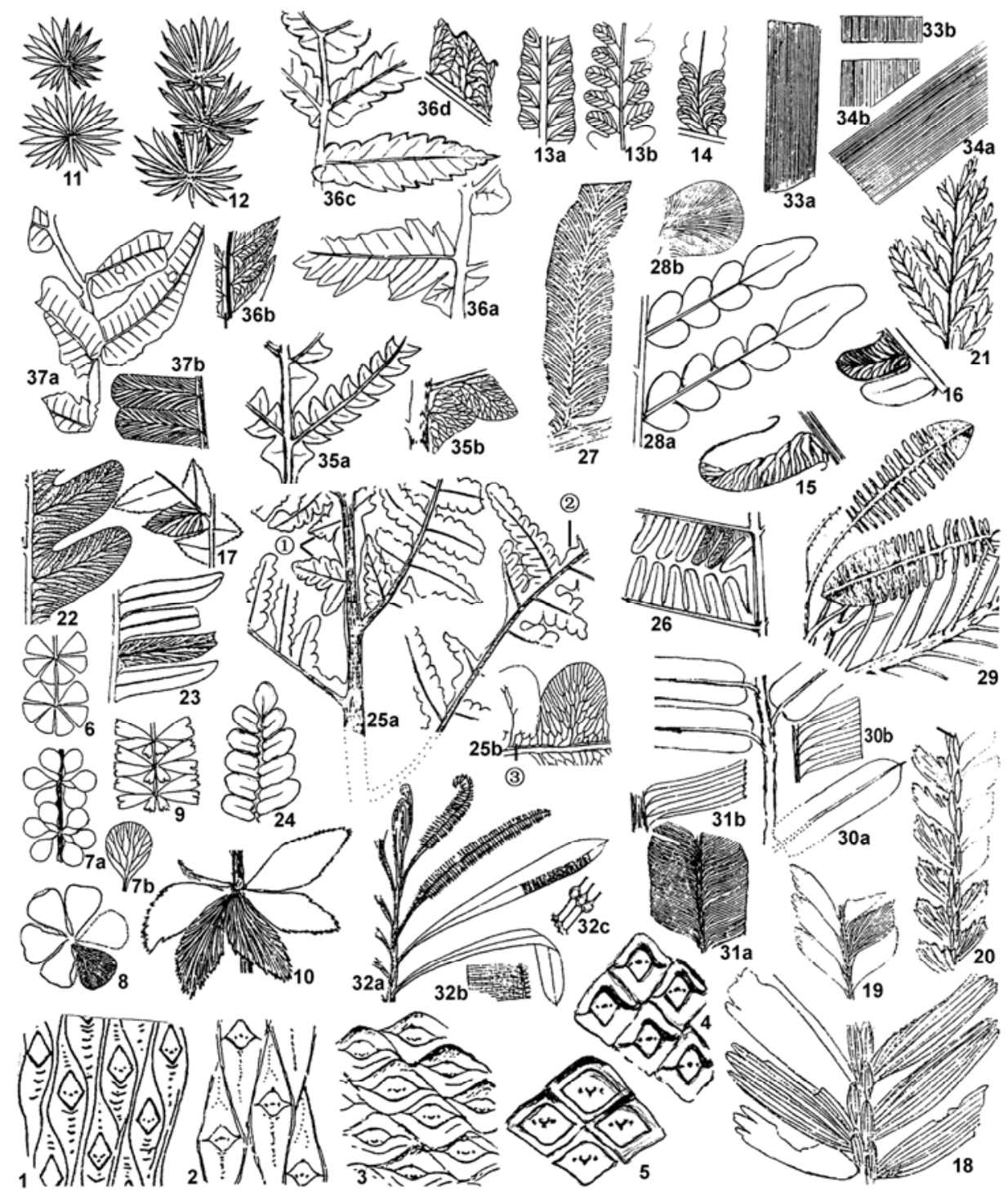

图 3 早期禹州植物群面貌示意图

石松植物鳞木目: 1. Lepidodendron posthumii Jongm. et Goth.; 2. L. szeianum Lee; 3. L. oculus-felis (Abb.) Zeill.; 4. L. yuzhouense Yang; 5. Cathaysiodendron henanense Yang. 节藏植物: 6. Sphenophyllum pseudocostae Kaw.; 7. S. rotundatum Halle, 7a, 示叶形状, 7b, 示叶脉; 8. S. minor (Sterg.) Gu et Zhi; 9. S. oblongifolium (Germ. et Kaulf.) Ung.; 10. S. thonii Mahr.; 11. Annularia orientalis Kaw.; 12. Lobatannularia sinensis (Halle) Halle. 真鰀植物: 13. Pecopteris unita Brongn., 13a. 示羽片浅裂, 13b, 羽片深裂为小羽片; 14. P. (Ptychocarpus) arcuata Halle; 15. P. flexuosa Yang; 16. P. flexa Yang; 17. Cladophlebis manchurica (Kaw.) Gu et Zhi. 前裸子植物漂叶目: 18. Tingia carbonica (Schenk) Halle; 19. T. hamaguchii Kon'no; 20. T. partita Halle. 种子䕬植物: 21. Sphenopteris tenuis Schenk; 22. Alethopteris norinii Halle; 23. Al. ascendens Halle; 24. Neuropteris ovata Haffm.; 25. Emplectopteridium alatum Kaw.; 25a, 三次羽状复叶, 具间羽片(1)和间小羽片(2), 25b, 示脉序和伴网眼(3); 26. Callipteridium tachangshanense (Sze) Lee; 27. Protoblechnum wongii Halle; 28. Odontopteris subcrenulata (Rost) Zeiller. 28a, 示硕叶, 28b, 示 脉序. 苏铁植物: 29. Procycas densinervioides Zhang et Mo 植物复原图; 30. Taeniopteris mucronata Kaw. 30a, 示叶形, 30b, 示脉序; $31 . T$. serrulata Halle 31a, 示叶形, 31b, 叶边缘具小刺; 32. Cathaysiocycas rectanervis Yang. 32a, 植物复原图, 32b, 示脉序及腺点痕, 32c, 示种子. 松柏植物: 33. Cordaites principalis (Germ.) Gein. 33a, 一段带形叶, 具平行脉, 33b, 脉间纹 3 4 条; 34. C. schenkii Halle 34a, 一段带形叶, 具 平行脉, 34b, 脉间纹 2 3 条. 前被子植物大羽羊齿目: 35. Emplectopteris triangularis Halle. 35a, 示茨叶形态, 35b, 示脉序; 36, Progigantonoclea henanensis (Chen Z. H. et Yang) Yang 示葓叶形态演化趋向, 36a, 羽片深裂, 羽片基部下行第一裂片三角形并下延至羽轴, 36b, 示单网脉序和伴网眼, 36c, 示羽片基部下边收缩成耳状, 边缘浅裂, 36d, 相邻侧脉联结成单网; 37. Cathaysiopteris whitei (Halle, Koidz.) Yang. 37a, 偋叶形态复原图, 37b, 示脉序. 本图是早期禹州植物群各类群基本面貌的示意图. 图中编号顺序按分类系统排列. 为反映植物群 总貌, 经精选后内容仍然较多类型复杂, 图中不便标出相应的比例尺 (图 4 和 5 同本图) 
齿目和苏铁类处于始现分化阶段. 此阶段包括本区 第 I, II 植物化石组合带, 相当于李星学等 ${ }^{[27]}$ 划分的 华北中部中期华夏植物群.

\section{2 中期禹州植物群: 中二叠世晚期 (茅口期)}

中二叠世茅口期, 本区处于 $11^{\circ} \mathrm{N}$ 赤道热带区, 仍为无季节分化的热带雨林气候. 沉积了两个大旋 回的三角洲体系 ${ }^{[4]}$. 自下而上历经三次由水下三角洲 平原-下三角洲平原-上三角洲平原至河口湾或海湾 环境的交替. 本期植物群组成(图 4)以节蒝植物芦木 科, 科达目, 树蒴型真薑, 苏铁类和大羽羊齿目为主. 前三者组成聚煤植物群. 大羽羊齿目处于首次繁盛 阶段. 此阶段包括本区第 III 植物化石组合带, 相当于 李星学等 ${ }^{[27}$ 划分华北中部的晚期华夏植物群 $\mathrm{A}$ 期的 早期.

本阶段后期, 五煤段沉积于下三角洲平原到水 下三角洲平原地带. 这种不利植物生长的环境, 一直 延续到晚期禹州植物群阶段的早期. 各类植物的发 育受到严重影响, 整个禹州植物群此时显得十分贫 乏. 直到六煤段沉积的中期才开始在浅水湖泊沼泽 等环境发育湿生植物群落, 并迅速衍生出大量新生 的植物类型.

\section{3 晚期禹州植物群：晚二叠世早期 (吴家坪期)}

本区在晚二叠世早期, 古地理位置移至 $15.3^{\circ} \mathrm{N}$ 赤道热带的干湿气候带. 再度处于两个大旋回的三 角洲体系环境. 早期旋回由六煤段至七煤段组成下 三角洲平原-上三角洲平原-三角洲边缘海湾环境, 总体地势低, 仅局部聚煤. 晚期旋回由八煤段组成 以上三角洲平原的分流河道和分流间湖泊, 沼泽泛 滥盆地为主. 总体地势升高, 干湿季气候变化明显 ${ }^{[4]}$. 本时期植被主要为灌木型群丛和部分池沼植物. 植 物群组分(图 5)则演替为草本的木贼科, 中生代型真 蓱, 漂叶目, 进步种子蒝盾籽目, 银杏类, 苏铁类和 大羽羊齿目为主. 大羽羊齿目处于再度繁盛及随之 突然消亡阶段. 蓱类植物极度衰落, 而种子植物占 统治地位. 后期有亚安加拉植物区松柏类分子入侵. 此阶段包括本区第 IV 和 V 植物化石组合带, 相当于 李星学等 ${ }^{[27]}$ 划分华北中部的晚期华夏植物群 $\mathrm{A}$ 期的 晚期. 直至临近晚二叠世早期末, 禹州植物群突然 消失. 晚二叠世晚期, 豫西和华北中部地区已处于
热带干旱气候环境, 出现了以裸子植物松柏类和进 步种子偋为主的欧美区系的内陆高地植物 “镁灰岩 植物”.

本文是《中国豫西二叠纪华夏植物群一一禹州植 物群》 ${ }^{[6]}$ 的后继文章. 关于禹州植物群各类群的一些 具体材料, 本文未予列入. 本文仅对该书中个别植物 化石名称作了修改(附录). 正如杨遵仪院士在该书序 言中指出的那样, “华夏植物群是一块瑰宝, 还有很 多内容尚待挖掘, 很多课题还需深入探讨”. 在现今 的华夏植物群研究中, 豫西禹州植物群实属极为罕 见的瑰宝. 它特有的构造古地理位置, 决定其具有 “北型南相”的过渡性特征. 使得该地区具有华北地 区二叠系最高的海相层位, 具有华北地区晚期华夏 植物群化石最丰富的最高层位. 由于长期处于热带 暖湿气候条件下, 造就了该区各类群植物化石丰富, 保存完好, 化石序列发育完整. 这些得天独厚的优越 条件为今后华北地区陆相地层建阶以及禹州植物群 各类群自然分类和生态特征等方面的深入研究提供 了绝好的资源基础. 在本文即将付印时, 收到张兴辽 等 ${ }^{[62]}$ 著的《河南省古生物地质遗迹资源》, 该书翔实 的古生物资料, 再次证实了豫西地区二叠纪禹州植 物群植物化石的丰盛程度和层序的完整性.

\section{附录}

本文对《中国豫西二叠纪华夏植物群一一禹州植

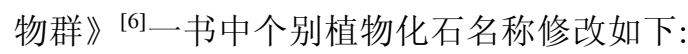

(1) Halle ${ }^{[47]}$ 根据山西太原的标本建立 Psygmophyllum multipartitum 时, 曾指出此种特征之 一为 “叶具背腹性, 叶边缘向内弯曲与叶柄的上表面 相连成勺形”, 并认为在材料充足时应建立新属. 原 苏联 Burago ${ }^{[63]}$ 也认为中国的 P. multipartitum 不具 Psygmophyllum 的特征. 本课题在豫西发现与 Halle 所述 P. multipartitum 特征一致的大量标本, 且形态 多样, 特征突出. 杨关秀等 ${ }^{[6]}$ 同意 Halle 意见建立新 属 Shenzhouphyllum, 但仍保留了 Psygmophyllum multipartitum一名, 并另建两个新种： $P$. aliretinervium, P. symetricum. 本文将此三种改归入 Shenzhouphyllum 属, 上述三个种应写为: Shenzhouphyllum multipartitum (Halle) Yang, S. aliretinervium (Xie) Yang et Xie, S. symetricum (Yang) Yang. 


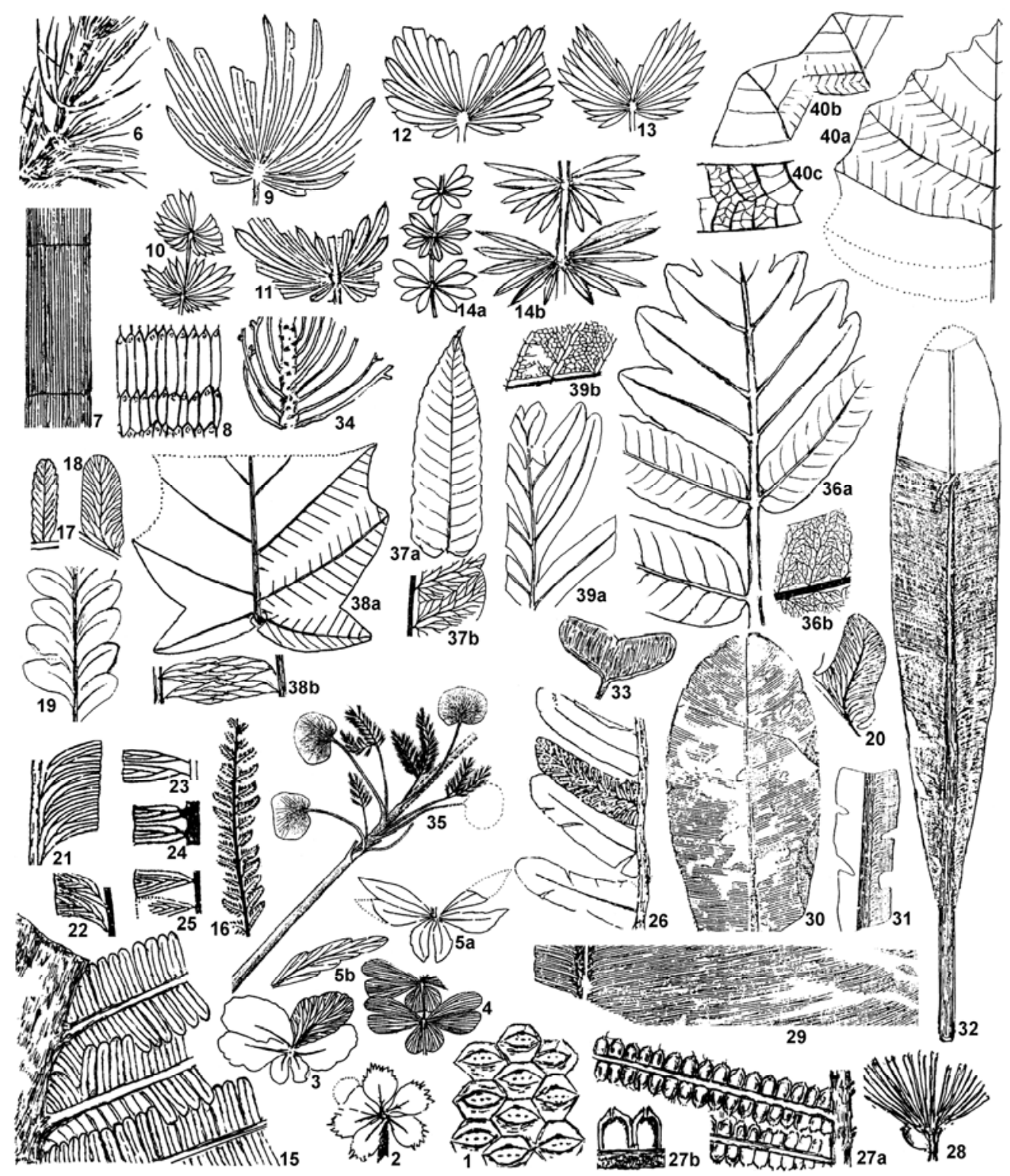

图 4 中期禹州植物群面貌示意图

石松植物鳞木目: 1. Yangzunyia henanensis Yang. 节蒝植物: 2. Sphenophyllum henanense Yang; 3. S. koboense Kob.; 4. S. speciosum (Royle) $\mathrm{McCl}$; 5. S. lobatum (Yang) Yang, 5a, 示叶形, 5b, 叶具中脉; 6. Asterophyllites longifolius (Sternb.) Brongn; 7. Paracalamites stenocostatus Gu et Zhi; 8. Calamites cf. gigas Brgt.; 9. Lobatannularia ensifolia (Halle) Halle; 10. L. minor Yang; 11. L. lingulata (Halle) Halle; 12. L. spatulata (He) emend. Yang; 13. L. papiliopsis Yang; 14. Annularia papilioformis (Kaw. ) Yang et Zhao, 14a, 幼叶形状, 14b, 成熟叶形状. 真硕植物: 15. Scolecopteris cathaysicus Yang et Wang, 营养葓叶; 16. Chansitheca kidstonii Halle; 17. Pecopteris obtusdentata Yang; 18. P. andersonii Halle; 19. P. nervosa (Halle) Wang; 20. P. lativenosa Halle; 21. Fascipteris (Ptychocarpus) densata Gu et Zhi; 22. F. hallei Kaw.; 23. F. chongsonensis (Kaw.) Li, Yao et Deng; 24. F. sinensis (Stockm. et Math. ) Gu et Zhi; 25. F. recta Gu et Zhi. 种子葓植物: 26. Neuropteridium polymorphum Halle. 苏铁 植物: 27. Phasmatocycas pinnata Yang. 27a, 末次生殖羽片, 羽状排列, 27b, 肧珠形状和漏斗状珠孔; 28. Primocycas chinensis Zhu et Du 掌状 大胞子叶, 左下侧有一卵形肧珠; 29. Taeniopteris nystroemii Halle; 30. T. norinii Halle; 31. T. tingii Halle; 32. T. henanensis Yang et Chen. 银杏 植物: 33. Saportea nervosa Halle. 松柏植物: 34. Dicranophyllum tenuifolium Yang. 分类不明裸子植物: 35. Nystroemia reniformis (Kaw.) Wang et al. 叶和生殖器官连生的复原图. 前有花植物大羽羊齿目: 36. Gigantonoclea cathaysiana Yang 36a, 烣型羽状复叶, 36b, 单网脉序; 37. G. tenuinervis Yang 37a, 羽片形状, 37b, 单网脉; 38. Monogigantonoclea grandidenia Yang et Sheng 38a, 边缘具巨齿的单叶, 38b, 单网脉; 39. Progigantopteris brevireticulatus Yang 39a, 羽状复叶, 39b, 维形重网脉; 40. Monogigantopteris clathroreticulatus Yang. 40a, 叶阔卵形, 40b, 两 级侧脉, $40 \mathrm{c}$, 重网脉 


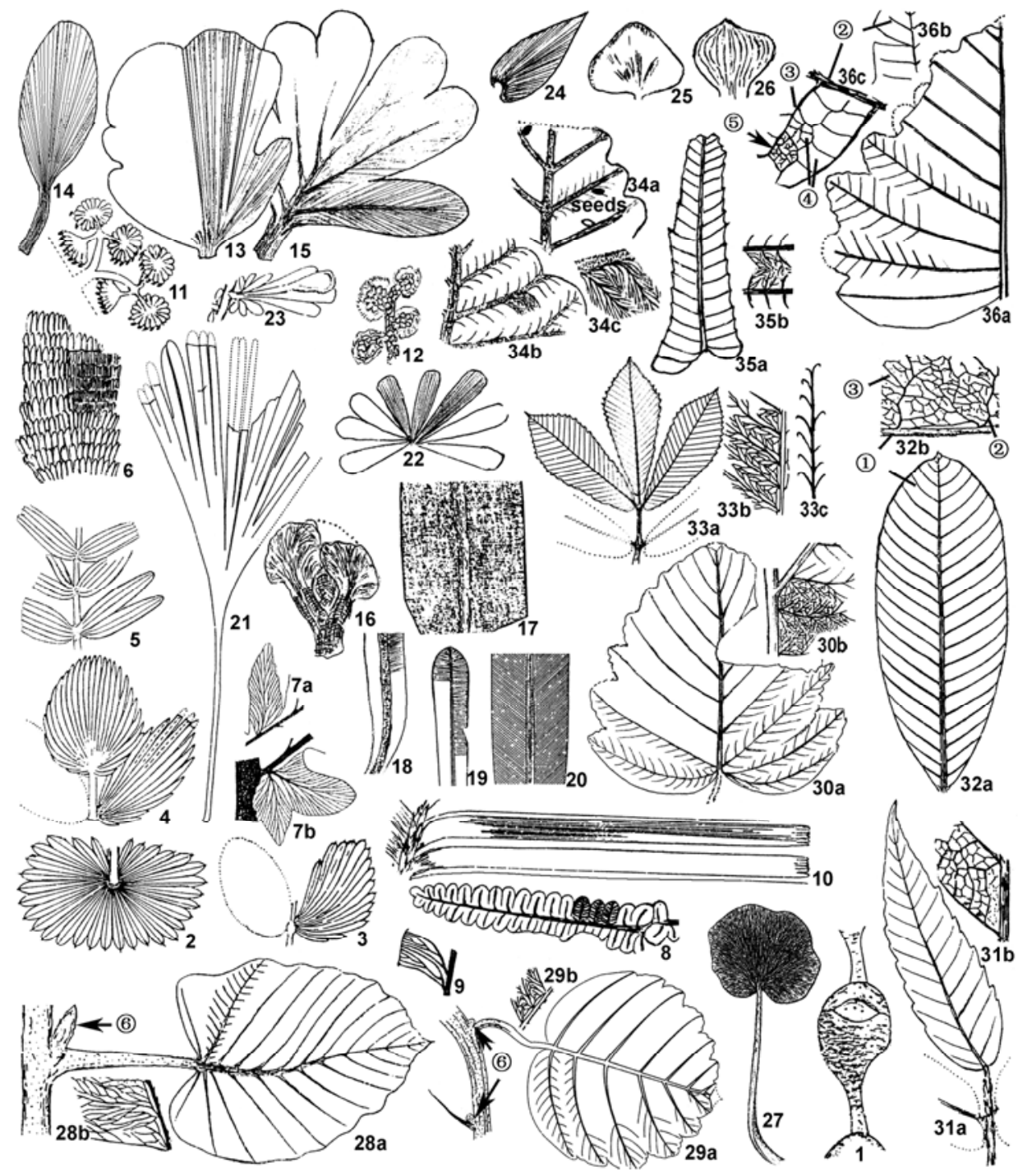

图 5 晚期禹州植物群面貌示意图

石松植物鳞木目: 1. Lepidodendron cervicisum Sze. 节茨植物: 2. Annularia mucronata Schenk; 3. Lobatannularia heianensis (Kod.) ) Kaw.; 4. L. cathaysiana Yao; 5. Schizoneura manchuriensis Kon'no; 6. Szecalamitina yangiae Doweld. 真葓植物: 7. Lixotheca (Cladophlebis) permica (Lee et Wang) Yao et Liu, 7a, 羽片基部上边小羽片形状, 7b, 羽片基部下边小羽片呈两瓣状; 8. Pecopteris (Asterotheca) crassinervis Yang et Chen; 9. Fascipteris stena Gu et Zhi. 前裸子植物漂叶目: 10. Tingia taeniata Yang et Chen Z. H. 种子蒴植物盾籽目: 11. Shenzhouspermum trichotomum Yang, Xie et $\mathrm{Wu} ; 12$. Shenzhoutheca aspergilliformis Yang et $\mathrm{Wu} ; 13$. Shenzhouphyllum undulatum (Yang) Yang et Xie; 14. S. spatulatum Xie et Wu; 15. S. multipartitum (Halle 1927, Yao) Yang. 苏铁植物: 16. Pania cycadina Yang; 17. Taeniopteris densissima Halle; 18. T. szei Chow; 19. T. spatulata McClell; 20. Lesleya (al Taeniopteris) cf. eckandti Germ. 银杏植物: 21. Sphenobaiera tenuistriata (Halle, 1927, Flor., 1936) Yang, 成熟叶复原图; 22. Rhipidopsis panii Chow; 23. Pseudorhipidopsis brevicaulis (P’an) Yang. 松柏植物: 24. Lepeophyllum sinense Yang et Xie; 25. Nephropsis cf. cordata Radez.; 26. Crassinervia kuznetskiana (Chachlov) Neub. 分类不明裸子植物: 27. Nystroemia reniformis (Kaw.) Wang et al. 前 有花植物大羽羊齿目: 28. Monogigantonoclea colocasifolia (Yang) Yang, 28a, 枝叶复原图, 具腋芽, 28b, 单网脉; 29. M. rotundifolia (Yang) Yang, 29a, 枝叶复原图, 具腋芽, 29b, 单网脉; 30. M. latiovata Yang et Wu, 30a, 叶形状, 30b, 单网脉; 31. Pinnagigantopteris lanceolatus Yang et Xie, 31a, 叶形状, 31b, 重网脉; 32. P. nicotianaefolia (Gu et Zhi) Yang, 32a, 叶形状, 32b, 重网脉; 33. Pinnagigantonoclea spatulata (Yang) Yang, 33a, 羽状复叶形状, 33b, 细脉中长网眼, 伴网眼明显, $33 \mathrm{c}$, 小叶变态为攀附的钩状器官; 34. Neogigantopteridium spiniferum Yang, 34a, 中脉和侧脉表面具瘤刺痕, 34b, 侧脉上部二岐分叉, 34c 相邻细脉 成叠雉状网脉; 35. Gigantogramme dengfengensis (Yang et Wu) Doweld, 35a, 叶边缘具短刺, 35b, 叶脉粗, 细脉呈单网; 36. Monogigantopteris densireticulatus Yang, 36a, 宽卵形单叶, 边缘重圆齿, 36b, 二级侧脉, 36c, 三级侧脉结成大网, 四、五级侧脉结成小网, 小网内有二岐分叉的 细脉. (1) 一级侧脉; (2) 二级侧脉; (3) 三级侧脉; (4) 重网脉; (5) 细脉; (6) 腋芽 
(2) 据 Doweld ${ }^{[64]}$ 意见, 对《中国豫西二叠纪华夏植 物群一禹州植物群》 ${ }^{[6]}$ 中三个重名化石更改如下:

(1) Siella Yang 改为 Szecalamitina Doweld; Siella leptocostata 改为 Szecalamitina yangiae Doweld.
(2) Hallea dengfengensis Yang et $\mathrm{Wu}$ 改为 Gigantogramme dengfengensis (Yang et Wu) Doweld.

(3) Acanthocladus xyloides Yang 改为 Gigantocladus xyloides (Yang) Doweld.

致谢本文为国家科技基础研究平台 “国家岩矿化石标本资源共享平台” 1012 年度项目成果. 参加本项目工作的还 有: 朱鸿, 曾学鲁, 谢建华, 陈瑶, 高岩, 赵继明, 吴跃辉, 盛阿兴, 孙克勤. 作者感谢美国 David L. Dicher 博 士，苗德岁博士和审稿人的建设性意见.

\section{参考文献}

1 刘本培, 全秋琦, 主编. 地史学教程(第三版). 北京: 地质出版社, 1996. 171-173

2 谢家荣. 勘探中国煤田的若干地质问题. 地质学报, 1953, 33: 15-28

3 王军, 孙柏年, 沈光隆. 豫西-浣北地区二叠纪植物地理区系性质探讨. 高校地质学报, 1999, 5: 76-91

4 杨起, 主编. 河南禹县晚古生代煤系沉积环境与聚煤特征. 北京: 地质出版社, 1987. 287

5 王自强. 华北古-中植代交替之际植物群落演替趋势. 科学通报, 1992, 37: 532-536

6 杨关秀, 王洪山, 曾学鲁, 等. 中国豫西二叠纪华夏植物群一禹州植物群. 北京: 地质出版社, 2006. 361

7 孙健初. 河南禹县密县煤田地质. 地质汇报, 1934, 24: 4-15

8 全国地层委员会编. 中国地层指南及中国地层指南说明书(修订版). 北京: 地质出版社, 2001. 59

9 杨关秀. 豫西禹县晚古生代含煤地层植物群顺序及区域地层的重新解释. 地球科学一武汉地质学院学报, 1985, 10(特刊): 145-161

10 Yang G X. Plant assemblage zones of late Paleozoic coal-bearing strata in the Yuxian County, west Henan and their stratigraphical significance. In: Jin Y G, Li C, eds. XIe Congres Inten de Stratig et de Geol du Carb Beijing 1987, Compte Rendu 3, 1989. 158-164

11 李星学. 东亚华夏植物群的鳞木类植物. 中国科学, 1980, 2: 166-171

12 杨关秀, 陈芬, 黄其胜. 古植物学. 北京: 地质出版社, 1994. 330

13 Yang G X, Wang H S, Sheng A X. Morphological and microscopical study on Scolecopteris from China. Palaeobotanist, 1996, 45: 238-246

14 Wang H S, Yang G X. Microscopic study of Qasimia from Permian in Western Henan Province, central China. Palaeobotanist, 1996, 45: $255-258$

15 刘照华, 耿宝印, 崔金钟, 等. 华夏齿叶表皮构造的研究. 植物分类学报, 1998, 36: 341-345

16 王军, 吴秀元. 晚古生代漂叶目植物的古生态学探讨. 古生物学报, 2004, 43: 72-85

17 王自强. 华北二叠纪大型古植物事件. 古生物学报, 1989, 28: 314-343

18 Zhang S Z, Mo Z G. On the occurrence of cycadophytes with slender growth habit in the Permian of China. Geol Soc Am Spec Pap, 1981, 187: $237-246$

19 杨关秀. 细茎苏铁植物新属 Cathaysiocycas 及其演化意义. 现代地质, 1990, 4: 38-43

20 Mamay S H. Paleozoic origin of the cycads. U. S. Geol Surv Prof Pap, 1976, 934: 1-48

21 王军, Pfefferkorn H W, 孙柏年, 等. 豫西早二叠世掌茨Chiropleris Kurr 和鬃籽羊齿 Nystroernia Hall 有机连接标本的发现. 科学通报, 2003, 48: 1965-1969

22 张宏达. 前有花植物亚门. 见: 张宏达, 等著. 种子植物系统学. 北京: 科学出版社, 2004. 66-71

23 杨关秀. 豫西禹县二叠纪大羽羊齿类的演化及其地质意义. 现代地质, 1987, 1: 173-195

24 黄本宏. 华夏植物群特有植物一一织羊齿 (Emplectopteris). 中国地质科学院沈阳地质矿产研究所所刊, 1986, 14: 137-144

25 夏国英, 丁蕴杰, 赵松银. 河南石炭-二叠纪含煤地层划分及生物群特征. 地层古生物论文集, 1987, 17: 98-128

26 李星学. 中国晚古生代陆相地层. 北京: 科学出版社, 1963. 168

27 李星学, 沈光隆, 田宝霖, 等. 我国石炭纪-二叠纪植物群的几个论题. 见: 李星学, 主编. 中国地质时期植物群. 广州: 广东科技出 版社, 1995. 190-228

28 李星学. 华夏植物群的起源, 演替与分布. 古生物学报, 1997, 36: 411-422

29 王自强, 王立新. 华北石千峰群下部晚二叠世植物化石. 中国地质科学院天津所所刊, 1986, 15: 1-80

30 黄本宏. 大兴安岭地区石炭二叠系及植物群. 北京: 地质出版社, 1993.141

31 赵修祜, 莫壮观, 张善祯, 等. 黔西滇东晚二叠世植物群. 见: 中国科学院南京地质古生物研究所, 编著. 黔西滇东晚二叠世含煤地 层和生物群. 北京: 科学出版社, 1980. 70-122 
32 姚兆奇. 华南“大羽羊齿煤系”和大羽羊齿植物群的时代. 古生物学报, 1978, 17: 81-89

33 朱肜. 福建二叠纪含煤地层及古生物群. 北京: 地质出版社. 1990. 127

34 梅美棠, 梁敦士. 江西中部二叠纪含煤地层植物化石组合. 煤炭学报, 1988, 4: 90-95

35 何锡麟, 梁敦士, 沈树忠. 中国江西二叠纪植物群研究. 徐州: 中国矿业大学出版社, 1996. 201

36 李富玉. 江西上饶以南的上饶组. 地层学杂志, 1986, 10: 298-303

37 Asama K. Permian plants from Maiya, Japan. I. Cathaysiopteris and Psygmophyllum. Bull Nat Sci Mus Tokyo, 1967, 10: 139-153

38 Asama K. Permian Plants from Maiya, Japan. II. Taeniopteris. Bull Nat Sci Mus Tokyo Ser C, Geol \& Paleontol, 1981, 7: 1-14

39 Mamay S H. New species of Gigantopteridaceae from the Lower Permian of Texas. Phytologia, 1986, 61: 311-315

40 Mamay S H. Gigantonoclea in the Lower Permian of Texas. Phytologia, 1988, 64: 330-332

41 Kawasaki S. The flora of the Heian System -Part 2 (Atlas). Bull Geol Surv Chosen, 1931, 6: 16-99

42 Kawasaki S. The flora of the Heian System -Part 2. Bull Geol Surv Chosen, 1934, 6: 47-311

43 Kawasaki S. Addition to the flora of the Heian System (including some specimens from NE China). Bull Geol Surv Chosen, 1939, 6: 1-37

44 Kawasaki S, Kon'no E. The flora of the Heian System - Part 3. Bull Geol Surv of Chosen, 1932, 6: 31-44

45 黄本宏. 内蒙古镶黄旗地区早二叠世植物化石. 见: 中国北方板块构造论文集编委会, 编. 中国北方板块构造论文集. 北京: 地质出 版社, 1986. 115-131

46 Ross C A, Ross J R P. Late Paleozoic sea levels and depositional sequences. In Ross C A, Haman D, eds. Timing and Depositional History of Eustatic Sequences: Constraints on Seismic Stratigraphy. Houston: Cushman Foundation, 1987. 137-150

47 Halle T G. Palaeozoic plants from Central Shansi. Acta Palaeontol Sin Ser A, 1927, 2: 1-316

48 Halle T G. On the habit of Gigantopteris. Geol Foren Stock For, 1929, 51: 236-242

49 陈汉清, 牛映雪. 太原西山上古生界多重地层划分. 山西地质, 1993, 8: 15-20

50 Hill C R, Wagner R H, EI-Khayal A A. Qasimia gen. nov. and early Marattia-like fern from the Permian of Saudi Arabia. Scr Geol, 1985, 79: $1-50$

51 杨关秀，陈芬. 古植物. 见: 候鸿飞, 等编著. 广东晚二叠世含煤地层和生物群. 北京：地质出版社, 1979. 104-139

52 韩健修. 东北地区古生物图册 (一) 古生代分册, 簙目. 北京地质出版社, 1980. 18-95

53 黄联盟, 梅美棠, 黄玉宁, 等. 闽西南早二叠世含煤地层及植物群. 北京: 煤炭工业出版社, 1989. 101

54 Liu L J, Yao Z Q. Comparison in leaf architecture between China and American species of Gigantopteridium. Acta Palaeontol Sin, 2002, 41: 322-333

55 刘陆军, 姚兆奇. 华南大羽羊齿植物一新属一Fujianopteris gen. nov. 古生物学报, 2004, 43: 472-488

56 姚兆奇, 刘陆军. 中国大羽羊齿植物分叉蒴叶的首次发现一兼论亚洲和北美大羽羊齿植物之异同. 古生物学报, 2002, 41: 308-321

57 潘钟祥. 川崎凡太郎与今野圆藏所述之 Rhipidopsis 河南禹县之发现. 中国地质学会志, 1937, 16: 261-280

58 欧阳舒, 王仁农. 豫皖地区平顶山砂岩段地质时代的探讨. 石油实验地质, 1985, 7: 141-147

59 李星学, 姚兆奇. 中国南部二叠纪含煤地层. 地层学杂志, 1980, 4: 241-255

60 田宝霖, 张连成. 贵州水城汪家寨矿区化石图册. 北京: 煤炭工业出版社, 1980. 110

61 朱鸿, 杨关秀, 盛阿兴. 河南禹州大风口剖面二叠纪地层古地磁研究. 地质学报, 1996, 70: 121-128

62 张兴辽, 席运宏, 李进化, 等. 河南省古生物地质遗迹资源. 北京: 地质出版社, 2011.265-304

63 Burago V I. Contribution to the morphology of the leaf genus Psygmophyllum (in Russian). Palaeontol J, 1982, 128-136

64 Doweld A B. New generic names for Permian plants of Cathaysia. Palaeoworld, 2012, 21: 137-138 